\title{
Globalization and Potential
}

As prepared for delivery

\author{
Robert B. Zoellick \\ President of the World Bank Group \\ at the 2008 Commencement of \\ The Paul H. Nitze School of Advanced International Studies \\ of the Johns Hopkins University
}

“Good afternoon, President Brody, Dean Einhorn, students, alumni, and parents.

It's a great honor to be here to share this special occasion, and to congratulate all of you - students and teachers, family and friends, for the many achievements that today's celebrations commemorate.

This is an important milestone. It took considerable effort, and I expect sacrifice, to be sitting where you are now. You should be proud of what you have achieved. Congratulations.

\section{A Step Back: to 1908}

Most of you are probably thinking about what comes next. Even if you have a job lined up already, you're wondering whether it's going to make the most of the knowledge and skills that you've gained, and give you the opportunities you're looking for to make your own contributions in various international fields.

But sometimes it's helpful to take a step back before plunging forward.

So let's turn the clock back...say, 100 hundred years.

In 1908, there were fewer people around-the global population was less than 2 billion. Only about 90 million people, of whom 90 percent were white, lived in the United States, and more than half lived in rural areas. Parts of the southwest United States were still unsettled, and southern Florida was a wilderness of mangrove swamps.

Here in Washington, DC, there was no SAIS yet. John Hopkins University had already been around for 38 years - though it was only a year since women were formally admitted to graduate study - and they wouldn't be undergraduates for another 60 years.

In 1908, a New York City regulation-the Sullivan Ordinance-tried to make it illegal for women to smoke in public. Now that one was ahead of its time. In 2002, Mayor Michael Bloomberg - a graduate of Johns Hopkins University, and whose public service skills were honed as Chair of the Board of Trustees signed the Smoke Free Air Act, banning smoking in public places in New York City, by both men and women.

In 1908, 15,000 women marched through the streets of New York City to demand shorter hours, more pay, and better working conditions, and British suffragettes began their campaign to secure the vote for women.

In some ways, 1908 foretold the world we see today. The first skyscrapers were just going up: the Singer Building in lower Manhattan, all of 47 stories, soon to be outdone by the 50-story Metropolitan Life Building. Nickleodeons were bringing movies to towns across the United States, with 200,000 customers a day at 5 cents per film - with piano accompaniment. Will Kellogg had introduced cornflakes, and fortunately for students around the world, the discovery of instant coffee was just around the corner.

It was an Olympic year, just like this one. The Games were originally to be held in Rome, but when Mount Vesuvius erupted unexpectedly in 1906 they were relocated to London. Irish athletes boycotted 
the Games because of Britain's refusal to give Ireland its independence, and at the opening ceremonies the American flag-bearer refused to lower Old Glory as he marched past the Royal Box. As one of his teammates, the Irish American Martin Sheridan explained, "this flag dips to no earthly king."

But the most dramatic moment of the Games occurred when the lead runner in the marathon, Dorando Pietri from Italy, stumbled into the stadium at the end of the race, headed in the wrong direction, collapsed several times, and had to be helped over the finish line by two officials. Pietri lost his gold medal because of the help he received. But he won international celebrity for his pluck and started a fashion for marathon running. His experience also offers a lesson to all graduates: to have a chance to win, you have to finish. So welcome to the finish line.

Of course, the distance runners among you know that the official length of a marathon-26.2 miles-is based on that London course, which turned out to be longer than the route from Marathon to Athens, so as to start the race at Windsor Castle and end it in front of the Royal Box. The extra mile or so that led poor Pietri to hit the wall has been the bane of many others over the century, too.

1908 was a time of enormous innovation. New discoveries in technology, transportation, and communication were beginning to change the way people lived.

People cleaned their homes with amazing new devices called vacuums, and men shaved with safety razors.

In 1908, Henry Ford introduced his Model T Ford, priced at $\$ 850$, when competing cars often cost $\$ 2000$ to $\$ 3000$. Ford's vision was to build a car that was well designed, well built, reliable, and, he said, "It will be low in price, that no man making a good salary will be unable to own one and enjoy with his family the blessing of hours of pleasure in God's great open spaces." It was also one of the first cars to have the steering wheel on the left.

The same year - on this very day 100 years ago, in fact - the Wright brothers registered their flying machine for a U.S.patent. A few months later, they would awe audiences with the first of a series of flying demonstrations in France. Before this time, planes could only stay aloft for a minute or two - but the Wright Flyer circled an airfield 77 times, for two and a half hours.

Lee De Forest made the first long-distance radio broadcast from the Eiffel Tower in Paris. And, at a rate of fifteen cents per word, the public could send messages across the Atlantic from the first transatlantic radio-telegraph stations, based in Glace Bay, Canada and Clifden, Ireland.

"Anything, everything, is possible," Thomas Edison declared in 1908, "the world is a vast storehouse of undiscovered energy."

Such potential manifested itself in bold demonstrations of man's global reach. President Teddy Roosevelt sent the "Great White Fleet" on a journey around the world to show the strength of American sea power. Robert Peary set off on his quest to be the first person to reach the North Pole. American engineers were cutting a fifty-mile canal through the Isthmus of Panama, to connect the Pacific and Atlantic oceans.

1908 was the year of both the first major commercial oil discovery in the Middle East and the beginnings of a conservation movement in the United States, prompted by Teddy Roosevelt's appreciation for protecting America's vast natural resources. "[T] he time has come to inquire seriously what will happen when our forests are gone, when the coal, the iron, the oil, and the gas are exhausted," said Roosevelt.

Technology was helping to make the world a smaller place in 1908, breaking down the barriers to trade and capital flows, and linking together distant regions of the world with very different endowments of land, labor, and capital. The fall in transportation costs created, for the first time, the possibility of a global economy. Ships, railroads, and soon automobiles and airplanes, made it possible to transport commodities and people across oceans and continents, while the spread of the telegraph, stock ticker, and telephone made international financial trading possible. 
These were circumstances that are familiar to us today-- we call it globalization.

Looking back a hundred years, we can see 1908 as a time of imagined potential - a period when it seemed that the future would be much better than the past.

Of course, there were danger signs. 1908 was also the year when a crisis erupted into public view in the Balkans. Yet a spirit of optimism prevailed.

In 1899, German biologist Ernst Haeckel had published The Riddle of the Universe, in which he argued that the fantastic scientific inventions of the early 20th Century would soon solve all the world's problems - including war.

In 1908, Norman Angell published his best seller, The Great Illusion, the title of which referred to the belief that there would soon be another major European war. Angell maintained that the new complex financial and commercial interdependence made war pointless and unlikely in the modern era.

David Starr Jordan, the president of a young Stanford University, predicted in 1913 that that "the Great War of Europe, ever threatening....will never come."

In June, 1914, a terrorist's bullet in Sarajevo pushed Europe over the edge into a new dark age. The hopeful prospects of 100 years ago were overwhelmed by the dangerous ideas of the early 20th Century: imperialism, fascism, authoritarianism, communism, corporatism, isolationism, and protectionism.

We learned anew that ideas can lead to cruelties and tragedies: wars, depressions, mass starvation, genocide, and economic disasters.

Tragically, the First World War, the Depression, and then the Second World War, provided cruel lessons for those who believed that economic integration and technological innovation alone would insure peace and prosperity.

In effect, it took the second half of the 20th Century to recover the degree of economic openness the world had lost in the first half of that century, and to bring the level of globalization back to the point where it had been one hundred years ago. Trade, as a percentage of world economic production, was roughly as high one hundred years ago as it is today.

\section{An Imagined Potential for the 21st Century}

During that climb back, in the midst of the savagery of World War II, Paul Nitze and Christian Herter had a vision of what could be. They had the foresight to understand that the United States, as the strongest military and economic power, had a responsibility to shape a new, post-war international order. And they recognized that this challenge would require men and women to acquire a new type of education and training.

So they founded the School of Advanced International Studies in 1943 to teach not only the traditional topics of international affairs and diplomacy, but also international economics, foreign languages, and cultures. They wanted to train leaders who could realize the potential of a post-war world that was more integrated, more open, more globalized.

Those of you who are graduating from SAIS today are the inheritors of Nitze's and Herter's imagined potential. After World War II, this meant combining security with economics; rebuilding an international economic system; helping colonies transition peacefully to independence; rolling back barriers to trade in goods, services, and capital; and encouraging the ideas of political and economic openness.

Today, you are graduating into a world of over six and a half billion people that is increasingly globalized. International trade and private financial flows have grown steadily, increasingly among developing as well 
as developed economies. People have become more mobile-almost 200 million people are now estimated to live outside their land of birth. And technology and knowledge are spreading at unprecedented speeds across countries: there is now one cell phone for every two humans on Earth.

Economists estimate that since 1820 world per capita real income has grown twenty times as fast as it did in the previous eight centuries. Over the last forty years, gains in life expectancy and literacy have been greater than at any time in human history.

Over the last twenty years alone, countries in Asia, Africa, and Latin America that have opened their economies have experienced dramatic increases in per capita income, progress in health and education, and faster growth than in developed countries. There are no examples of fast-growing countries that followed a policy of closing themselves off from other economies.

We've also seen the downsides of this globalization: people who are not included in the opportunities; changes that create anxieties; environmental degradation and climate change; the rapid transmission of viruses; the spread of dangerous weapons; and violent groups resisting modernity, to the point that they want to turn the clock back over a thousand years.

In the coming decades, it will be up to you to shape this new era of globalization. The challenges you will face defy easy predictions and solutions. Your SAIS education has equipped you with the knowledge and skills needed to navigate complex issues and organizations, work with diverse people and groups, and adapt to the changing international environment.

Let's take a quick look at the world of development in the $21^{\text {st }}$ Century, at some of the challenges facing the World Bank.

The World Bank - like SAIS - was established during the Second World War to build a more hopeful future. Our first loan was to France, to help with our mission of reconstructing Europe and Japan. Our first loans to the developing world were to Chile in 1948.

Today, some sixty years on, the World Bank Group must recast its mission for very different times.

We must still focus on basic needs, especially in Africa. That means working to achieve the Millennium Development Goals - overcoming poverty and malnutrition, and improving health, education, and the environment, so that by 2015, boys and girls will be going to primary school, mothers and children will be receiving healthcare, pregnancies will be safer, and hunger and malnutrition will no longer claim the lives of 3.5 million children under five every year.

To help support this agenda, developed countries have pledged to boost their overseas assistance. Last year, our concessional financing arm for the poorest countries, the International Development Association, received pledges at historic levels.

But development is about much more than aid. The context for our work is changing. So must our approach.

Between 1995 and 2005, 17 countries of sub-Saharan Africa, with about one third of the population, but without great energy resources, grew, on average, 5.5 percent. During that same decade, another eight African countries with energy resources - and with another third of the population - grew, on average, 7.4 percent.

These Africans know they must address poverty, disease, and the lack of quality education. High food prices now put many at greater risk. But these Africans also want something more. They want economic growth. They want investment. They seek the same things Europeans sought sixty years ago: energy, infrastructure, stronger regional integration connected to global markets, and expanding privates sectors that can tap the enterprise and creativity of businesses, small and large. 
Yet another third of Africans - and too many people in other regions - are facing the special challenge of states that are breaking down or are struggling to rebuild after conflict. In his book The Bottom Billion, Paul Collier pointed out that some 70 percent of those at the bottom live in countries that have suffered civil wars. This strife plagues their neighbors, too.

Of course, these countries need aid. But more than that, they need security and development that go hand in hand, mutually reinforcing one another. For decades, experts viewed these countries as just harder cases to which to apply the basic development models. I think we need a new approach, more adeptly combining considerations of security, rule of law, good governance and anti-corruption, reintegration of former combatants, basic infrastructure, community development, and small scale private sector business and financing that gets people to work. They need visible progress, in real time.

Sixty years ago, the "R" in the Bank's formal name, the International Bank for Reconstruction and Development, stood for the challenge of reconstructing Europe and Japan. Today, it challenges us to reconstruct broken states, and to stop them breaking again. From Liberia to Afghanistan, from Haiti to Cambodia, this will be your generation's task. This will not be a question just for those who choose work in development. How to manage failed states, and their fall-out, will be a compelling issue in all your lives.

We must also adjust to serve the needs of those that have ridden the wave of globalization to the status of middle income countries. We need new approaches to harness the market and incentives to provide opportunities for all. Earlier this month I was in Mexico and Colombia, where we are employing innovative financial products to offer student loans to poor families, and expand financial services to those that have been barred from the formal economy for centuries. We are insuring against earthquakes and backing conditional cash transfers that give subsidies to low income families when they send their children to school or get health checks. We are working with the private and public sectors to develop innovating financing for infrastructure. We can use innovative approaches to flexible financing to back climate change strategies for adaptation and mitigation, and beyond that, new instruments for carbon trading.

Of course, the rising economic powers, especially the BRICs, like rising powers of past eras, call for particular attention. We need to integrate them effectively as "responsible stakeholders" in the international economic system that has helped enable their success. That means assisting them with their pressing development problems, while working with them as they extend outward-within their region and beyond, particularly to Africa.

Indeed, it is striking that during this period of financial turmoil, unlike the 1980s and 1990s, these rising economic powers not only fared better, but offered alternative poles of growth. Whether we consider this development through the perspective of portfolio diversification for the international economy, or multipolarity, it will be a feature of the era of globalization you will shape.

These larger, growing economies will expect a greater voice in international affairs, in determining the evolution of the international system's institutions, rules, and norms. It is hard to imagine how the world will be able to deal with any major global question - whether climate change, energy security, food prices, or nuclear proliferation - without their cooperation.

We also must focus on the international regimes and tools to address regional and global public goods whether involving health and the environment, or the systems that enable trade and finance to flow. In doing so, the World Bank Group must broaden our engagement with other multilateral bodies - the UN system, the WTO, IMF, and regional development banks. We must work more closely with civil society groups and NGOs. We must leverage the strength of private financing and business.

Earlier this week, I attended the World Economic Forum meeting in Egypt, and shortly before visited Saudi Arabia. The World Bank Group also has a role to play in supporting development and hope in the Arab World. Other than in energy, these diverse countries have lagged behind the interconnections of globalization. That is changing. They are seeking to advance an inclusive and sustainable globalization. And we can assist. 


\section{Conclusion}

The challenges we face at the World Bank Group offer you just one perspective on this new era of globalization that you will be responsible for shaping.

Just as in 1908, there are positive portents of the future.

But just as in 1908, the future still must be written.

In a recent online poll, more than a thousand people in six developed countries were asked if they had positive or negative views about globalization. The answers were predominantly negative: those polled in the UK, France, and Spain were about three times more likely to say globalization was having a negative rather than a positive effect on their countries. In the United States, only 18 percent had a positive view of globalization, as opposed to 48 percent negative.

From my highly informal survey of asking university students around the world, I found the most hopeful for globalization to be in Chongqing, China.

As the history of the 20th Century revealed, a peaceful world united by economic opportunity is a choice, not an inevitability. If we seek a world of freedom and prosperity, we - each of you - has to make it happen.

When I attended graduate school, the United States was still suffering from losing a war in Vietnam. It was a time of economic strain caused by oil shocks and stagflation that signaled to some that America's economic dynamism had run its course. Renewed tensions with the Soviet Union were building.

Yet in my 30's, I witnessed extraordinary changes in the global political landscape. Germany unified. The Warsaw Pact dissolved. The Soviet Union and its empire ceased to exist. Mexico chose to be both Latin American and North American. And I saw America regain its economic ingenuity, productivity, and entrepreneurial faith in itself.

Some look around the world and see intractable problems.

But, as a friend recently reminded me, it's worth asking whether today's problems are more intractable than:

- The conditions of Western Europe before the Marshall Plan and the creation of NATO;

- U.S.-China relations before the Shanghai Communiqué;

- Israeli-Egyptian relations before the Camp David Agreement and peace treaty;

- The Cold War division of Germany and Europe before the creation of a Europe whole and free;

- The gulf in relations between Mexico and the U.S. before NAFTA and Mexico's new democracy;

- The absence of negotiations between Israel and its neighbors before the Madrid Peace Conference;

- Or the chaos of the Balkans before the Dayton Agreement.

And today we approach the seemingly intractable with new strengths: the promise of medicine that can help rid the world of many of our worst diseases; micronutrients that could end malnutrition if distributed to the people in need; mobile technologies that could offer broadband connections to the poorest rural areas; information technologies that can leap borders and join minds with the spark of creative reasoning.

But it will take the ingenuity, energy, and persistence of the greatest resource - people - to apply these new tools effectively. 
So I share this modest lesson with you, in the hope it might be of some help at a point in your life: The human spirit is indomitable. Each individual matters. The seeds of policies and innovations planted today can influence tomorrow. And free men and women can move the world.

Therefore, your choices do matter. Your ideas can have influence. Your actions will affect others. And given your good fortune to live in this time and place, your contributions are of special moment: Because the future of this new era of globalization will be up to you.

Best Wishes and Good Luck." 